Niepełnosprawność. Dyskursy pedagogiki specjalnej

Marta Jurczyk

Uniwersytet Gdański

\title{
Fantazmat emancypacji? Konstruowanie dyskursu seksualności osób z niepełnosprawnością intelektualną a aksjologiczna pustka podmiotowości
}

\begin{abstract}
Artykuł ma na celu ukazanie procesu kształtowania się (anty)podmiotowości osób niepełnosprawnych intelektualnie przez osoby pozostające z nimi w relacjach edukacyjnych/terapeutycznych. Tym samym działania te skupione wokół kategorii seksualności i jej konstruowania są rodzajem fantazmatu emancypacji. Emancypacja sama w sobie stanowi w świetle prezentowanych rozważań raczej otwarty projekt i potrzebę ciągłego (re)definiowania.
\end{abstract}

Słowa kluczowe: emancypacja, seksualność, podmiotowość, niepełnosprawność, dyskurs

\section{Phantasm of emancipation? Constructing the sexual discourse of people with intellectual disabilities and the axiological emptiness of subjectivity}

This text is intended to show the process of shaping the (anti)subjectivity of people with intellectual disabilities by those who are with them in the educational / therapeutic relationship. By the same token - these activities, centered around the categories of sexuality and constructing them, are some sort of phantasm of emancipation. Emancipation itself is rather an open project and the need for continuous re-definition.

Keywords: emancipation, sexuality, subjectivity, disability, discourse

\section{Wprowadzenie}

Przełom XX i XXI wieku, jak wskazuje D. Pogórska-Jachnik, przyniósł wiele korzystnych zmian w sytuacji osób niepełnosprawnych w Polsce, zwłaszcza w płaszczyźnie realizacji zróżnicowanych modeli niepełnosprawności - modelu społecznego oraz opartego na prawach [Podgórska-Jachnik 2005, s. 295]. Co jednak istotne, o ile nastąpił wyraźny wzrost poziomu aspiracji edukacyjnych i zawodo- 
wych osób z niepełnosprawnością, jak wskazuje D. Podgórska-Jachnik, postawy społeczne wobec dokonywanych zmian nadal jednak skutecznie blokują rzeczywiste otwarcie modelu społecznego. Tym samym pozostaje on nadal w sferze jedynie deklaracji, nie zaś praktyki. Praktyka ta natomiast determinowana jest przez swoistego rodzaju zawłaszczanie podmiotowości osób z niepełnosprawnością intelektualną. Maria Czerepaniak-Walczak wiąże podmiotowość z możliwością dokonywania wyborów (w szerszym kontekście życiowym również z realizacją aspiracji), ale i z ponoszeniem wynikających stąd konsekwencji (odpowiedzialnością) [Czerepaniak-Walczak 2006]. L. Witkowski natomiast wskazuje, że pedagogiczna podmiotowość związana jest przede wszystkim z możliwością stawiania pytań o potencjał nieautorytatywności, stopień redukowania wezwań humanizmu, charakter krytycyzmu, skalę i zakres dążeń emancypacyjnych [Giroux, Witkowski 2010, s. 58-59].

Rozważania nad konstytuowaniem (anty)podmiotowości osób z niepełnosprawnością intelektualną, zogniskowanych wokół kategorii reprezentacji ich seksualności (prawa do jej posiadania/wyrażania), opieram na doktorskim projekcie badań własnych. Przedmiotem badań niniejszego projektu był dyskurs seksualności osób z niepełnosprawnością intelektualną, którego parametry (kategorie, wartościowanie, cenzura) zostały zidentyfikowane $\mathrm{w}$ dramowych rekonstrukcjach badanych praktyków (nauczycieli, wychowawców, terapeutów - pozostających $w$ relacji edukacyjnej/terapeutycznej z osobami z niepełnosprawnością intelektualną) [Jurczyk 2015]. Badania empiryczne zostały umieszczone w paradygmacie krytycznym i dyskursywnym, a dokładnie - w matrycy metodologicznej etnografii performatywnej, $w$ warstwie samego działania badawczego oraz Krytycznej Analizy Dyskursu jako formy analizy zebranych wypowiedzi badanych uzyskanych w trakcie działania dramowego (które to uznałam za tekst konstruujący dyskurs seksualności osób z niepełnosprawnością intelektualną przez badanych nauczycieli i terapeutów). Same badania empiryczne trwały 3,5 roku, a dobór próby liczył łącznie około 280 nauczycieli/terapeutów/wychowawców. Wyróżnione ramy dyskursu, a w nich poszczególne kategorie dyskursywne, nie stanowią jednak istoty niniejszego artykułu. Celem niniejszego artykułu jest ukazanie mechanizmów konstytuowania procesu emancypacji osób z niepełnosprawnością intelektualną jako fantazmatu, konstruowanego przez uprawomocnione podmioty w soczewce kategorii seksualności, ogniskującej antypodmiotowe (wobec osób z niepełnosprawnością intelektualną) działania. 


\section{Paradygmat emancypacyjny i seksualność}

Paradygmat emancypacyjny stanowi - według A. Krause - perspektywę nie tyle finalnie zdefiniowaną co nieustająco otwartą [Krause 2010, s. 209]. Faktem pozostaje kwestia ustępowania tradycjonalistycznego podejścia postrzegania pomocy osobom z niepełnosprawnością na rzecz autonomii i podmiotowości oraz jak wskazuje J. Doroszewska - na „przywracanie godności ludzkiej osobom niepełnosprawnym [Doroszewska 1989, s. 32]”. Trudność emancypacji w przypadku procesów zarówno dydaktycznych, rehabilitacyjnych, jak i terapeutycznych $\mathrm{w}$ polu problemowym pedagogiki specjalnej jest związana $\mathrm{z}$ faktem zrozumiałej świadomości ograniczenia osiągania pewnych poziomów autonomii przez osobę niepełnosprawną, czy też „konsumowania” jej wytworów (autonomii) [Doroszewska 1989, s. 203]. Ryzyko emancypujących praktyk zatem wynikać może niejednokrotnie z faktu nadawania pewnej autonomii osobom niepełnosprawnym, dla których owy poziom tej autonomii mógłby stanowić kwestię niebezpieczną. Opór emancypacyjny tym samym może rozprzestrzeniać się na wielu płaszczyznach społecznego funkcjonowania. Wyznaczany może być przez marginesy społecznego dekodowania kultury - stereotypy, uprzedzenia, odsuwanie od społeczeństwa. Emancypacja jako postulowana kategoria „dobrych rozwiązań, podnosząca ważność kwestii ze społecznym osiąganiem autonomii przez osoby niepełnosprawne w polu problemowym seksualności owych osób, staje się zatem punktem problematycznym. Kwestią problematyczną uruchamiania autonomii osób z niepełnosprawnością intelektualną (i emancypacyjny charakter ewentualnych projektowych praktyk) zatrzymuje się na poziomie pytania o umiejętność korzystania przez osobę niepełnosprawną z owej autonomii. Ta zaś kwestia projektuje za sobą szereg pytań o odpowiednią edukację i przygotowanie zarówno na poziomie jednostki niepełnosprawnej (jak korzystać z osiągniętej autonomii), jak i w polu edukacyjnym kształcenia profesjonalnej kadry (jak uczyć osoby niepełnosprawne rozumieć i korzystać z osiąganej autonomii).

Dyskurs seksualności osób z niepełnosprawnością intelektualną nie stanowi iście nowatorskiego przedmiotu badań uczonych, tym samym problem postaw społecznych wobec seksualności niepełnosprawnych ulegał pewnym tendencjom i przeobrażeniom. Wskazać tu można takich badaczy, jak A. Draft [1983], który ugruntował swoistego rodzaju niezaprzeczalny fakt prawa do własnej seksualności osób z niepełnosprawnością intelektualną, jak również do jej wyrażania. Co jednak istotne, jak podają W. Kempton i E. Kahn [1991, s. 93-111] - prawo to było skutecznie ograniczane przez przeświadczenie o tożsamości niepełnosprawnych jako „wiecznych dzieci”, jak również jako osoby potencjalnie stanowiące zagrożenie ze względu na niemożność kontrolowania własnych popędów. 
Dokonując analizy wielu różnych postaw i ich społecznych przeobrażeń wobec seksualności osób z niepełnosprawnością intelektualną, możemy przyjąć podział za K. Nowak-Lipińską [1996, s. 56] na rygorystyczną i tradycjonalistyczną, zdezorientowania i bezradności czy też pasywności. Uwspółcześniając niejako owo podejście wyróżnić można 4 reakcje społeczne, które to podaje R. Kijak za B. Ludlow [2009, s. 50], jako najlepiej obrazujące spektrum postaw wobec seksualności niepełnosprawnych:

- „Mit Kuby Rozpruwacza” - gdzie niepełnosprawność intelektualna determinuje nadpobudliwość seksualną, w całkowitej niezdolności do kontrolowania zachowań seksualnych oraz przy braku umiejętności kontroli zachowań seksualnie poprawnych; tym samym konieczne jest stałe odosobnienie w placówkach zamkniętych lub leczenie represyjne;

- „Mit Frankensteina” - niepełnosprawność intelektualna generuje swoistego rodzaju dewiacje seksualne, gdzie zachowania seksualne wyrażane są w nienaturalnych formach, tym samym zachowania te wymagają stałej kontroli zewnętrznej, a osoby z niepełnosprawnością intelektualną powinny przebywać wraz z innymi osobami "swojego pokroju”[Kijak 2009];

- „Mit Piotrusia Pana” - gdzie niepełnosprawność intelektualna automatycznie warunkuje aseksualność, całkowicie pozbawianą chęci jej wyrażania; wyrażanie to odbywać się może jedynie $w$ formach niedojrzałych, zatem nie wymagają zdefiniowanych interwencji dotyczących edukacji seksualnej, co jednak istotne, wskazuje się na konieczność izolacji w celu ochrony i zapewnienia bezpieczeństwa przed wykorzystaniem przez innych;

- Upośledzenie umysłowe = seksualność stłumiona, gdzie „osoby upośledzone mają normalne odruchy seksualne i pragnienia, które są blokowane przez restrykcyjną politykę oraz izolację, więc wymagają zachęty, szkolenia oraz możliwości do rozwijania akceptowanych form wyrażania seksualności" [Ludlow 1991, s. 4].

Istotny również, z perspektywy dynamiki konstruowania (anty)podmiotowości osób z niepełnosprawnością intelektualną wydaje się koncept społecznego stosunku do seksualności osób z niepełnosprawnością intelektualną, sformułowany przez E.H. Quinta [1999], który definiuje swoistego rodzaju postawę jako „strategię milczenia". Opiera się ona na wykluczeniu osób z niepełnosprawnością intelektualną z pełnego uczestnictwa $\mathrm{w}$ życiu społecznym, poprzez strategie bagatelizowania ich potrzeb przy świadomym przemilczaniu praktyk separacyjnych. 


\section{Podmiot i emancypacja}

B. Śliwerski, analizując uwikłania procesów emancypacyjnych w kształtowanie podmiotowości, podkreśla, że: „centralną rolę nad polityką oświatową i wychowawczą państw zachodnioeuropejskich odgrywało pojęcie emancypacji, przez którą rozumiano nie tylko jako wyzwolenie jednostki spod społecznej przemocy poprzez aktywny udział w kreowaniu i współtworzeniu antyrepresyjnych form wychowania i współżycia, ale i autonomię, wyzwolenie i uzyskanie przez młodego człowieka wewnętrznej niezależności od autorytetów" [Śliwerski 2001, s. 264-265].

Co istotne, jak podkreśla A. Męczkowska „relacje władzy oplatające podmiot, konstytuujące jego «ja» przenikające go na wskroś, ustalające go w pozycji przedmiotu sprawowania rządów, mają charakter dyskursywny" [Męczkowska 2006, s. 190]. Jak wskazuje dalej A. Męczkowska, przedmiot pedagogicznego zainteresowania stanowić powinien projekt takiej pedagogii, która, zachowując świadomość wpisanych w nią mechanizmów opresji oraz opresyjnego charakteru konstytuowania się podmiotowości, przy świadomości o chwiejnym potencjale jej samej, staje się jednakowoż swoistego rodzaju „orędowniczką uznania podmiotowego statusu podmiotów edukacji" [Męczkowska 2006, s. 214], przy zachowaniu zdolności artykulacji jej emancypacyjnych prób. Wskazuje tutaj przy okazji na koncepcję emancypacji zasadzającą się na trzech filarach: uwzględnienia zjawiska decentracji kanałów sprawowania władzy, zakwestionowania dychotomicznego ujęcia emancypacji oraz zakwestionowanie teleologicznej formuły postępu społecznego [Męczkowska 2006, s. 215). W przypadku pierwszego aspektu istota tegoż opiera się na postrzeganiu władzy w perspektywie wielorakich modalności, a samo jej oddziaływanie uważa się za zapośredniczone w pojęciu autonomii podmiotu. Aspekt zakwestionowania dychotomicznego ujęcia emancypacji rozumie ona przez odniesienie samej emancypacji nie do ukształtowania nowego człowieka i dalej - nowego społeczeństwa, ale do umiejętności badawczego wytyczenia granic możliwych do przekroczenia przez wolny podmiot. Natomiast w przypadku zakwestionowania teleologicznej formuły postępu społecznego wiąże się z „luzowaniem zastanych relacji władzy, wytwarzającym nisze dla realizowania się parcjalnej wolności podmiotów" [Męczkowska 2006, s. 2015].

Istotne zatem zdaje się wskazanie A. Krause na "drogę ku emancypacji” [Krause 2010, s. 209], gdzie same wyznaczniki podmiotowości i autonomii stanowią silne podwaliny współczesnego modelu postrzegania osoby z niepełnosprawnością, jednak - jak wskazuje Krause - stanowią jedynie silną nadbudowę teoretyczną przy wciąż niewystarczającej przekładalności funkcjonalnej. Praktyka ta, będąca realnym działaniem edukacyjno-rehabilitacyjnym z osobą z niepełnosprawnością 
intelektualną, determinuje podmiotowość samej tej osoby na zasadach ograniczonego przyzwolenia, a autonomiczność oznacza nie tyle wolność czy możliwość wyboru, co drogę rehabilitacyjną czy sposób oddziaływań edukacyjnych. Tym samym niejednokrotnie, na co wskazuje Krause, dla części pedagogów specjalnych autonomia osoby z niepełnosprawnością intelektualną oznacza de facto samodzielne ubranie się.

Ważne zatem staje się wskazanie na podłoże tak konstruowanych praktyk, w których projekty emancypacyjne mają charakter jedynie postulatywny. Jak pisze Bourdieu, ,„[o]becność lub nieobecność danej grupy w oficjalnej klasyfikacji zależy od tego czy potrafi ona przekonać innych do tego, by ją uznali, by ją zauważyli i zaakceptowali, a zatem zależy od jej zdolności uzyskania - najczęściej po długich walkach - miejsca w porządku społecznym (...) [Bourdieu 2005, s. 591]. Tym samym to pełnosprawni klasyfikują i konstytuują obecność niepełnosprawnych w życiu społecznym i reglamentują ich partycypację w udziale określonych dóbr społecznych, co stanowi samo w sobie istotę głębokiego uprzedmiotowienia ze względu na fakt "pozbawiania mowy wykluczonych". Jak wskazuje Z. Bauman: „każda granica dzieli terytorium na dwie części: tu i tam, to co wewnątrz i to co na zewnątrz, nas i onych. Dlatego też każda autodefinicja ostatecznie jest stwierdzeniem istnienia opozycji naznaczonej obecnością pewnej cechy różnicującej po jednej stronie tej granicy i brakiem - po drugiej (...). Tymczasem skupiając niby swą uwagę na tym, co sie dzieje po jednej stronie tej granicy, próbują stworzyć wrażenie, że poprzestają jedynie na wyartykułowaniu atrybutów, przysługujących jednej tylko stronie; przemilczają zaś nieuniknione następstwa w postaci podziałów wywołanych przez te całe operacje. (...) rozdzielenie tych dwóch przestrzeni i ustanowienie między nimi pewnej specyficznej relacji jest celem i raison d'être owego zabiegu definicyjnego, nie zaś jego efektem ubocznym" [Bauman 1998, s. 7]. Wytwarzanie pozoru zdaje sie być cechą charakterystyczną każdego procesu konstruowania rzeczywistości, opartego na bardziej lub mniej ideologicznie określonych i usystematyzowanych podstawach [Starego 2012, s. 122]. Jak podkreśla T. Szkudlarek, dotyczy to w szczególności rzeczywistości celowego - bo opartego na logice wprowadzania w życie określonych idei - wychowania [Szkudlarek, Śliwerski 2000, s. 35-37]. T. Szkudlarek wprowadza jeszcze jeden istotny dla tego procesu element, mianowicie „epistemologię uniku” [Starego 2012, s. 357], która oznacza, że założeniowość określonych koncepcji czy idei jest konstytutywnym elementem tożsamości ją promujących, czy w taki lub inny sposób będących jej częścią. W efekcie epistemologiczny unik oznacza „uparte nieakceptowanie”, czy też wytworzenie się „takich procedur poznawczych, które pozwalają na niedostrzeganie pozorności kreowanego świata" [Szkudlarek, Śliwerski 2000, s. 35], a które zabezpieczają przed utratą tożsamości warunkowaną przez istnienie rzeczywistości założeniowej. 
Seksualność osób z niepełnosprawnością intelektualną jawi się wypowiedziach badanych w kategoriach niebezpiecznych, a samo bezpieczeństwo uznawane jest za kategorię najwyższej instancji podejmowania działań interwencyjnych. Jak konkluduje Z. Bauman, „dla podejmujących 'środki bezpieczeństwa' w imieniu ludzi, których bezpieczeństwo zostało uznane - milcząco bądź jawnie za zagrożone, przedmiotem działania stają się byty, których jedynym znaczeniem jest zagrożenie (...) - to które już stanowią, które dopiero mogą stanowić lub o którego stanowienie da się je wiarygodnie posądzić" [Bauman 2012, s. 70]. Jak wskazuje dalej, odmawianie podmiotowości odbywa się tutaj na zasadzie dyskwalifikacji określonych celów jako potencjalnych partnerów dialogu, gdyż „cokolwiek powiedzą, cokolwiek powiedzieliby gdyby dano im głos, jest a priori uznawane za nieistotne, jeśli w ogóle wysłuchane” [Bauman 2012, s. 70]. Zabiegiem dodatkowo wzmacniającym samo „odmawianie podmiotowości” jest, jak wskazuje Bauman za E. Levinasem, proces „wymazania twarzy”, opierający się na przeświadczeniu o słuszności własnego działania etycznego, które to niejako niweluje „problem bezpieczeństwa” Innego. W istocie proces obezwładniania twarzy Innego jako potencjalnie niebezpiecznej (mimo że pozostaje ona nieuzbrojona i nie oparta na przymusie), stanowi zasadniczą część idei samej dehumanizacji [Bauman 2012]. Zabieg wykorzystywania słabości Innego i praktyka odzierania "z twarzy" (wystarczy raz) w naturalny sposób determinuje mechanizmy przemocy wobec niego, sama słabość zaś otwiera bezkresną przestrzeń etycznej "troski” [Bauman 2012, s. 71].

\section{Fantazmat emancypacji?}

Zatem fantazmat emancypacji polega na konstytuowaniu niepełnosprawności intelektualnej jako prawomocnego wyjątku przez osoby z niepełnosprawnością intelektualną, gdzie sam dyskurs ich seksualności stanowi jedynie pewnego rodzaju soczewkę ich antypodmiotowości. Istotnej egzemplifikacji tego fantazmatu dokonuje G. Agamben, wskazując na różnicowanie „Ludu”, rozumianego jako całość ciała politycznego i "ludu” definiowanego przez podgrupę biednych, wykluczonych i uciśnionych. Polaryzację tę „określa pierwotna struktura polityczna: nagie życie (lud), istnienie polityczne (lud), wyłączenie i włączenie, dzo_ i bios (...). Jest on tym, co nie może być włączone w całość, której jest częścią, i nie może należeć do zbioru, w którym zawsze sie zawiera" [Agamben 2008, s. 242-243]. To „włączające wyłączenie”, stanowi relacje nadającą jej elementom podstawową nieokreśloność [Agamben 2008, s. 148]. Brak tożsamości „ludu” stanowi bowiem konsekwencje konstytutywnego „wyjątku” stojącego u podstaw struktury suwe- 
renności - tym, co nadaje jej obowiązywanie jest „wyrzucenie" poza wymiar obowiązywania prawa zjawisk, które, stając sie wyjątkiem, nadają mu prawomocność.

Istotne zatem zdaje się tutaj wskazanie A. Krause dotyczące postulatów emancypacji osób z niepełnosprawnością intelektualną, które to „o ile przebijają się do tzw. edukacji masowej, to poszanowanie wolności wyboru i faktycznej, a nie tylko deklarowanej, podmiotowości w przypadku osób niepełnosprawnych przedstawia wiele do życzenia (...) w formie bardziej wysublimowanej, ukrytej, emancypacja przegrywa z wyobrażeniami pełnosprawnych urzędników, jak ma wyglądać życie człowieka niepełnosprawnego, z formami oferty edukacyjnej, metodami pracy, przygotowaniem do zawodu pedagoga specjalnego, czy praktyką pedagogiczną" [Krause 2013].

Badania własne nad seksualnością osób z niepełnosprawnością intelektualną pozwalają na określenie swoistego rodzaju istotnej perspektywy tej kategorii. Perspektywa ta stanowi proces i dynamikę konstruowania (przez osoby zaangażowane w relacje edukacyjne/terapeutyczne/wychowawcze) dyskursu seksualności osób $\mathrm{z}$ niepełnosprawnością intelektualną $\mathrm{w}$ optyce prowokowanego działania performatywnego, $\mathrm{w}$ wyniku którego określone formacje dyskursywne miały możliwość zaistnienia i wybrzmienia w przestrzeni, która dotychczas zdecydowanie obligowała do przyjmowania postaw $\mathrm{w}$ duchu poprawności politycznej i istoty podmiotowości osób z niepełnosprawnością intelektualną. W momencie zderzenia z performatywną sytuacją dramową, w której to badani musieli dokonać próby rozwiązania konfliktu osadzonego w problematyce seksualności dorosłych osób z niepełnosprawnością intelektualną, uruchomiły się w nich rytuały pozostające $w$ dyspozycji i reprezentowane przez badanych jako określoną grupę społeczną. Wzorce te, stale wzmacnianie, jak wskazuje P. McLaren [1993, s. 45-51], stanowią kluczowy aspekt procesu produkcji kulturowej, a także formę pewnego rodzaju legitymizacji znaczenia, które to (znaczenie) umożliwia funkcjonowanie jednostek $\mathrm{w}$ ramach norm społecznych i reprezentowanych praktyk uznawanych za poprawne (politycznie, społecznie czy też kulturowo). Tym samym, "pobudzenie" w wyniku warsztatu dramowego określonych rytuałów i wzorców postrzegania seksualności - jak również mówienia o niej - stanowi swoistego rodzaju demaskację deklaratywnej poprawności w myśl postulowanych idei podmiotowości i emancypacji osób z niepełnosprawnością intelektualną. Co istotne jednak, zachodzi tutaj również zjawisko swoistego rodzaju „ambiwalencji profesjonalizmu", który deklaratywnie jest pojmowany przez realizację postulatów autonomii i podmiotowości osób z niepełnosprawnością intelektualną, $\mathrm{w}$ konsekwencji intencjonalnego i operacyjnego uruchomienia pracy rytuałów - rozumiany jest przez projektowanie praktyk przemocowych (tak przemocy symbolicznej, jak i fizycznej). 
Seksualność osób z niepełnosprawnością intelektualną stanowi zatem dyskursywny konstrukt praktyk wykluczających, które dychotomicznie wyznaczają struktury klasyfikacyjne Innego. Jak wskazuje Canguilhem, „to, co jest w danej dziedzinie wartościowań odmienne od tego, co preferowane, nie jest neutralne, ale odpychające, a ściślej mówiąc odrzucone, obrzydliwe" [Canguilhem 2000]. Różnica, którą wytwarzają antagonistyczne realne granice, pozwala na określenie się tożsamości znormalizowanej wewnętrzności, dzięki leżącemu po drugiej stronie "konstytutywnemu zewnętrzu” [Mouffe 2005], rozumianemu jako obszar Innego. Jak dodaje K. Starego, „proces konstruowania zewnętrza należy zatem postrzegać w kategoriach jego funkcjonalności wobec konstrukcji homogenicznej całości społecznej" [Starego 2013, s. 263]. W tym kontekście Judith Butler wskazuje nie tyle na konstytuowanie się tożsamości „onych” (w dialektycznej logice normalnego i patologicznego), ile na produkowaną przez „ekskluzywną matrycę" domenę bytów "nędznych" czy "pogardzanych" [Butler 1993], "które, nie stanowiąc jeszcze 'podmiotów', określają konstytutywne zewnętrze dla domeny samych podmiotów" [Butler 1993].

Dyskurs seksualności osób z niepełnosprawnością intelektualną jawi się jako szczególny przypadek kategorii „podklasy”. Jak pisze Gans, stanowi ona rodzaj etykiety, która pełni funkcję normatywną oraz pozycjonującą różne kategorie ludzi, poza rzeczywistością społeczną, utrwalając tym samym przekonanie, że nie są oni - lub być nie powinni - częścią społeczeństwa. Staje się tym samym niejawnym sposobem wykluczenia [Gans 1995, s. 61]. Podobną perspektywę kreśli Z. Bauman, który twierdzi, że „termin 'podklasa' należy do wizji społeczeństwa, które nie obejmuje wszystkich ludzi, jacy zgłaszają pretensję do jego członkostwa, wizji takiej całości, która jest mniejsza od sumy jej części składowych" [Bauman 1998]. 'Podklasa' przywodzi na myśl obraz kategorii, jaka nie mieści się w żadnej z klas składających się na całość społeczną - kategorii umieszczonej nie tyle u spodu, co poza zasięgiem społecznej hierarchii; kategorii ludzi pozbawionych roli do odegrania, ludzi, którzy nie mają niczego użytecznego do zaoferowania społeczeństwu i po których społeczeństwo wkładu się nie spodziewa; a więc kategorii, która nie może rościć sobie praw z tytułu pożytków, jakie na bieżąco ogółowi przynosi, a i też nie ma dostępu do dróg, jakie mogłyby ją na powrót na łono społeczeństwa sprowadzić; a gdyby dostęp miała, i tak by owymi drogami nie podążyła ze względu na «ułomności behawioralne» - dotkliwe wady charakteru, czyniące ją niezdolną do uczestniczenia w normalnym życiu społecznym". Życie i seksualność osób z niepełnosprawnością intelektualną jest sprowadzane do funkcji biologicznych - mówiąc językiem Giorgio Agambena - do „nagiego życia” jako synonimu wyłączenia [Agamben 2008, s. 30]. Nie jest to jednak równoznaczne z jedynie biologicznym kontekstem dyskursywnych praktyk i biologicznym kontekstem wykluczania z porządku prawnego czy politycznego, przeciwnie, są 
włączone, ale na sposób „włączającego wyłączenia”. Oznacza to, że nieformalnie są częścią całości rzeczywistości, ale formalnie zostają pozbawione praw z wynikających z przynależności do tej całości. Istotą wyłączenia jest więc redukcja tożsamości społecznej, w efekcie czego "nagie życie” staje się również życiem „odartym z ludzkich własności" [Agamben 2008, s. 298].

\section{Emancypacja jako otwarty projekt?}

Jak wskazuje Z. Janiszewska-Nieścioruk [2013, s. 259] - najczęściej paternalistyczna postawa charakteryzująca się negacją, przesadną kontrolą lub hamowaniem jakichkolwiek przejawów i potrzeb seksualnych, skutkuje bezpośrednio nadużywaniem władzy przez sprawowanie określonej kontroli wobec osób $\mathrm{z}$ niepełnosprawnością intelektualną. Istotne wskazanie stanowi zatem sama kategoria emancypacji, tak istotna dla pedagogiki specjalnej i podmiotowości osób z niepełnosprawnością intelektualną, która to niejako tworzy punkt wyjścia jakiegokolwiek mówienia/działania o seksualności osób z niepełnosprawnością intelektualną. Jak wskazuje A. Krause, „obszary, gdzie widziałbym konieczność niezwłocznej poprawy, lokalizuję zarówno w środowisku akademickim pedagogów specjalnych, jak i w praktyce pedagogicznej. Do praktycznej wykładni pedagogiki emancypacyjnej $\mathrm{w}$ procesie kształcenia pedagogów specjalnych oraz w konkretnych działaniach rehabilitacyjno-edukacyjnych, jeszcze nam daleko" [Krause 2013]. T. Żółkowska przyjmując koncepcję E. Laclau, wskazuje, że emancypacja jako „puste znaczące” mogłaby stanowić swoisty uniwersalizm, „unieważniający różnicę między Wykluczonymi (osobami niepełnosprawnymi), a jednocześnie określać tożsamość tych osób jako różniącą je od Typowych" [Żółkowska 2014, s. 15]. Ponadto, podkreśla, że "trzeba poszukiwać czynników kształtujących tożsamość osoby niepełnosprawnej i jednocześnie określić możliwości tych, którzy stwarzają wykluczenie" [Żółkowska 2014]. Taki projekt emancypacji może stanowić nie fantazmat, a postulat pracy zarówno z osobami z niepełnosprawnością intelektualną, jak i projekt działań edukacyjnych w programach studiów i kursów dla osób bezpośrednio zaangażowanych w pracę edukacyjną, terapeutyczną i rewalidacyjną z osobami niepełnosprawnymi.

\section{Bibliografia}

Agamben G. (2008), Homo sacer. Suwerenna władza i nagie życie, Prószynski i S-ka, Warszawa. Bauman Z. (1998), Prawodawcy i tłumacze, Wydawnictwo IFiS PAN, Warszawa.

Bauman Z. (2012), Straty uboczne, Wydawnictwo Uniwersytetu Jagiellońskiego, Kraków. 
Bauman Z. (1998), Zawrotna kariera "podklasy” [w:] Przeglad socjologiczny, maj-czerwiec, nr 1-2, http://www.tezeusz.pl/cms/tz/index.php?id=354 [dostęp: 22.09.2017].

Bourdieu P. (2005), Dystynkcja. Społeczna krytyka władzy sądzenia, Wydawnictwo Naukowe Scholar, Warszawa.

Butler J. (1993), Bodies that Matter. On the Discursive Limits of "Sex", Routledge, New YorkLondon.

Canguilhem G. (2000), Normalne i patologiczne, Wydawnictwo słowo/obraz terytoria, Gdańsk.

Czerepaniak-Walczak M. (2006), Pedagogika emancypacyjna, Gdańsk.

Doroszewska J. (1989), Pedagogika specjalna, Zakład Narodowy im. Ossolińskich, Wrocław.

Draft A. (1983), Sex Education and Counseling for Mentally Handicapped People, Tunbridge Wells, Costello.

Gans H.J. (1995), The War Against the Poor. The Underclass and Antipoverty Policy, Basic Book.

Giroux H.A., Witkowski L. (red.) (2010), Edukacja i sfera publiczna, idee i doświadczenia pedagogiki radykalnej, Oficyna Wydawnicza „Impuls”, Kraków.

Janiszewska-Nieścioruk Z. (2013), Respektowanie i egzekwowanie praw seksualnych osób z niepetnosprawnościa - palacy, nierozwiąany problem [w:] Człowiek z niepetnosprawnościa w rezerwacie przestrzeni publicznej, Z. Gajdzica (red.), Oficyna Wydawnicza „Impuls”, Kraków

Jurczyk M. (2015), Nie(petno)normatywna seksualność i (nie)uświadomiona władza. Seksualność niepetnosprawnych intelektualnie w kontekście pytania o emancypację [w:] Codzienność, performatywność, demokracja: pedagogika wobec norm życiowych i problematyki nienormatywności, Kopciewicz L., Simlat-Żuk B. (red.), Wydawnictwo Naukowe Katedra, Gdańsk.

Kempton W., Kahn E. (1991), Sexuality and people with intellectual disabilities in Greece, Sexuality \& Disability, Springer.

Kijak R. (2009), Seks i niepetnosprawność. Doświadczenia seksualne osób z niepetnosprawnościa intelektualna, Oficyna Wydawnicza „Impuls”, Kraków.

Krause A. (2013), Teoretyczne inspiracje pedagogiki specjalnej-pedagogika emancypacyjna, „Studia Edukacyjne" nr 28.

Krause A. (2010), Wspótczesne paradygmaty pedagogiki specjalnej, Oficyna Wydawnicza „Impuls”, Kraków.

Ludlow B. (1991), Contemporary issues in sexuality and mental retardation [w:] Advances in mental retardation and developmental disabilities, A.R. Gable (red.), J. Kingsley Publishers, London.

McLaren P. (1993), Schooling as a Ritual Performance, Routledge.

Męczkowska A. (2006), Podmiot i pedagogika. Od oświeceniowej utopii ku podkrytycznej dekonstrukcji, Wydawnictwo DSW TWP, Wrocław.

Mouffe Ch. (2017), Agonistyczne przestrzenie publiczne i demokratyczna polityka, przeł. J. Maciejczyk, „Recykling idei”, http://recyklingidei.pl/mouffe_agonistyczne_przestrzenie_publiczne_polityka_demokratyczna [dostęp: 23.09.2017].

Nowak-Lipińska K. (1996), Pytania o miejsce edukacji seksualnej osób z głębszym upośledzeniem umystowym [w:] Społeczeństwo wobec autonomii osób niepetnosprawnych: od diagnoz do prognoz i działań, W. Dykcik (red.), Wydawnictwo Eruditius, Poznań.

Podgórska-Jachnik D. (2015), „Piss on Pity - Disability”. Odrzucenie litości doznawanej przez osoby niepetnosprawne jako przejaw ich dążeń emancypacyjnych [w:] Różnice, edukacja, inkluzja, T. Szkudlarek, A. Komorowska-Zielony (red.), Wydawnictwo Uniwersytetu Gdańskiego, Gdańsk. 
Quint E.H. (1999), Gynecologycal health care for adolescents with developmental disabilities, „Adolescence Medicine".

Starego K. (2012), Ukryty program i konstruowanie, znaczeń wiedzy o obywatelskości w gimnazjum, niepublikowana praca doktorska, Uniwersytet Gdański, Gdańsk.

Starego K. (2013), Biedny jako Inny - orientalizacja i dehumanizacja biednych w procesie dyskursywnego konstruowania reprezentacji codzienności, „,Rocznik Pedagogiczny”, nr 36.

Starego K. (2012), O społecznych konsekwencjach autodefinicji intelektualistów ( $i$ ich edukacyjnych konotacjach), "Rocznik Pedagogiczny”, nr 35

Szkudlarek T., Śliwerski B. (2000), Wyzwania pedagogiki krytycznej i antypedagogiki, Oficyna Wydawnicza „Impuls”, Kraków.

Śliwerski B. (2011), Wspótczesne nurty i teorie wychowania, Oficyna Wydawnicza „Impuls”, Kraków.

Żółkowska T. (2014), Dlaczego emancypacja osób niepetnosprawnych powinna być „pustym znaczacym"?, „Interdyscyplinarne Konteksty Pedagogiki Specjalnej”, nr 5. 